Animal Production and Environment Received on: 19/10/2021

Accepted on: 12/01/2022

\title{
Biochemical profile of castrated and uncastrated male goats supplemented with vitamin $\mathbf{E}$ or not
}

Perfil bioquímico de caprinos machos castrados e não castrados suplementados ou não com vitamina $E$

${ }^{1 *}$ PEREIRA, Anderson Lopes

https://orcid.org/0000-0003-1791-4477

${ }^{2}$ BRITO, Danilo Rodrigues Barros

https://orcid.org/0000-0001-5073-3681

${ }^{2}$ CUTRIM JÚNIOR, José Antônio Alves

https://orcid.org/0000-0003-3126-7624
${ }^{2}$ CASTRO, Lucimeire Amorim
https://orcid.org/0000-0001-5473-725X

${ }^{3}$ SILVA, Igor Cassiano Saraiva

https://orcid.org/0000-0002-0404-6669

${ }^{4}$ CHAVES, Daniel Praseres;

https://orcid.org/0000-0002-5320-1469

${ }^{2}$ SILVA NETO, Carlos Nunes da

https://orcid.org/0000-0002-4564-0795

\footnotetext{
${ }^{1}$ Universidade Federal da Paraíba - UFPB, Centro de Ciências Agrárias - Campus II, CEP: 58.397-000 - Areia/PB - Rodovia PB 079 - Km 12, Brasil

${ }^{2}$ Instituto Federal de Educação Ciência e Tecnologia do Maranhão - IFMA Campus Maracanã, Avenida dos Cúrios, s/n, Vila Esperança, São Luís/MA, CEP 65095-460, Brasil

${ }^{3}$ Universidade Federal do Ceará - UFC, Departamento de Zootecnia, Campus Pici, Av. Mister Hull, s/n, CEP 60455-760 Fortaleza/CE, Brasil

${ }^{4}$ Universidade Estadual do Maranhão - UEMA, Cidade Universitária Paulo VI, São Luís/MA, Brasil

"Mail for correspondence: anderson.lopes10@ hotmail.com
}

\section{ABSTRACT}

The objective of this study was to evaluate the biochemical parameters of goats submitted to castration or not and receiving supplementation with vitamin E or not. A total of 24 goats, uncastrated (12 experimental units) and castrated males (12 experimental units), with average body weight weighing $17.6 \mathrm{~kg} \pm 2.67 \mathrm{~kg}$, were distributed in a completely randomized design in a $2 \times 2$ factorial arrangement, with two animal conditions (castrated and uncastrated male) and vitamin $\mathrm{E}$ supplementation (with and without supplementation), with six replications. There was an effect of treatments $(\mathrm{P}<0.05)$ over time for all studied variables. There was an effect of vitamin supplementation $(\mathrm{P}<0.05)$ for phosphorus, iron, protein, glucose, aspartate aminotransferase (AST), alanine aminotransferase (ALP) and gamma-glutamyltransferase (GGT). Vitamin supplementation increased glucose, creatinine and GTT levels over time, and reduced levels of phosphorus, iron, protein, albumin, AST and ALP. We conclude that vitamin E influenced the biochemical parameters studied, but castration did not change the 
biochemical profile of goats, regardless of whether they were supplemented with vitamin E or not.

Key words: clinical parameters, small ruminants, supplementation

\section{RESUMO}

Objetivou-se avaliar os parâmetros bioquímicos de caprinos submetidos ou não a castração e recebendo ou não suplementação com vitamina E. Um total de 24 caprinos, machos não castrados (12 unidades experimentais) e machos castrados (12 unidades experimentais), com peso corporal médio de $17,6 \mathrm{~kg} \pm 2,67 \mathrm{~kg}$, foram distribuídos em delineamento inteiramente casualizado em arranjo fatorial $2 \times 2$, sendo duas condições animais (macho castrado e não castrado) e suplementação com vitamina $E$ (com e sem suplementação), com seis repetições. Houve efeito dos tratamentos $(\mathrm{P}<0,05)$ ao longo do tempo para todas as variáveis estudadas. Houve efeito da suplementação vitamínica $(\mathrm{P}<0,05)$ para fósforo, ferro, proteína, glicose, aspartato aminotransferase (AST), alanina aminotransferase (ALP) e gama-glutamiltransferase (GGT). A suplementação vitamínica elevou os níveis de glicose, creatinina e GTT ao longo do tempo, e reduziu os níveis de fósforo, ferro, proteína, albumina, AST e ALP. Concluímos que a vitamina E influenciou nos parâmetros bioquímicos estudados, porém a castração não alterou o perfil bioquímico de caprinos, independentemente de estarem suplementados ou não com a vitamina $\mathrm{E}$.

Palavras-chave: parâmetros clínicos, pequenos ruminantes, suplementação

\section{INTRODUCTION}

The State of Maranhão in Brazil has potential for goat livestock since the soil and climate characteristics are beneficial for the development of animals. However, the production systems within the State are still old and with low technological adherence, in addition to irregular nutrition due to the low quality of food, constituting factors which compromise the productive performance and the health of goat herds, and in turn hindering the economic development of the activity in which efficient measures are needed to reduce production costs (Teixeira et al., 2016).

The metabolic state of the animals can be evaluated through clinical examinations correlating with different paraclinical tests, mainly evaluating the metabolic and hormonal profile, antioxidant indices and mineral levels. Deficiency of metabolites and vitamins can delay reproductive development, fetal growth and milk production (Samimi et al., 2021).

Testosterone exerts an androgenic effect on the development and maintenance of the male reproductive system, and an anabolic effect on the development of muscles, kidneys and liver (Olaifa, 2018), regulation in the oxidative phase of carbohydrates and improves lipid metabolism (Gupta et al., 2008), which may cause changes in the hematological parameters of the animals (Olaifa, 2018). Castration is a procedure in which the testicles are removed or the vessels that irrigate the testicles are cut, and these procedures vary according to the castration method used (Mohammed \& James, 2013). 
Vitamin E can be integrated into animal feed in different ways, with the most common and active form in foods being $\alpha$-tocopherol (Mendonça Júnior et al., 2011), and is related to several functions in the body. Camargo et al. (2010) state that this vitamin acts in protecting the lipid membrane, receptors and cellular components involved in modulating the immune response of animals.

Knowing that the effects of vitamin E, administered intramuscularly in goats can cause metabolic changes and the clinical status of the animals, it is necessary to analyze the impacts that this supplementation will cause in neutered and non-castrated animals which are supplemented or not with vitamin $\mathrm{E}$ through serum biochemistry. Thus, the objective of this study was to evaluate the biochemical parameters of goats submitted to castration or not and receiving supplementation with vitamin E or not.

\section{MATERIALS AND METHODS}

The experiment was carried out in the Sheep and Goat Sector of the Federal Institute of Education, Science and Technology of Maranhão, Campus São Luís - Maracanã, located in the city of São Luís, MA, Brazil (2³7'01' south and $44^{\circ} 16^{\prime} 19^{\prime}$ " west). A total of 24 goats, 12 non-castrated and 12 castrated males, with an initial age of eight months and without a defined racial pattern (SPRD), with a mean body weight (BW) of 17.6 $\mathrm{kg} \pm 2.67 \mathrm{~kg}$, were finished after 90 days in a confinement system, with the first 15 days of the experimental period destined for adaptation of the animals to the diets and facilities, and 75 days for data collection. The castration procedure was performed using burdizzo-type castrating pliers. All procedures with animals were carried out in accordance with the regulations of the Animal Use Committee of the State University of Londrina (217/2014).

The animals were identified with earrings and dewormed using $10 \mathrm{~g} \cdot \mathrm{kg}^{-1}$ of moxidectin (Cydectin, Fort Dodge Animal Health, Campinas, SP, Brazil) at a dose of $1 \mathrm{ml} .50 \mathrm{~kg}^{-1}$ of body weight (BW) and were then distributed in pens measuring $1.50 \mathrm{~m} \times 1.70 \mathrm{~m}$ (one animal per pen) with a concrete floor, covered with sawdust, according to a completely randomized design in a $2 \times 2$ factorial arrangement, with six replications. The investigated treatments consisted of two animal conditions (castrated and noncastrated males) and vitamin $\mathrm{E}$ supplementation (with and without supplementation).

The experimental diets were based on Tifton 85 grass hay (Cynodon spp.) and concentrated ration of ground corn and soybean meal, being an isoprotein and isoenergetic diet (Table 1). The diets were formulated for animals with $20 \mathrm{~kg}$ BW for an average daily gain of 150 g.day ${ }^{-1}$, according to the NRC (National Research Council, 2007) with daily adjustment, allowing for leftovers of up to $15 \%$. Water and mineral mixture were fed ad libitum to the animals. The feed was supplied twice a day at 8:00 and 17:00 h. 
Table 1. Composition of experimental diets $\left(\mathrm{g} \cdot \mathrm{Kg}^{-1} \mathrm{DM}\right.$ ) of castrated and uncastrated goats with no defined racial pattern (SPRD), supplemented with vitamin E

\begin{tabular}{|c|c|c|}
\hline \multirow{2}{*}{ Ingredients } & \multicolumn{2}{|c|}{ Animal Condition } \\
\hline & Castrated & Uncastrated \\
\hline Tyfton-85 Hay & 382.8 & 425.8 \\
\hline Corn grounded & 367.0 & 369.9 \\
\hline Soybean meal & 147.3 & 113.6 \\
\hline Wheat meal & 91.3 & 80.1 \\
\hline Limestone & 11.3 & 10.3 \\
\hline Mineral supplement $^{2}$ & 0.3 & 0.3 \\
\hline \multicolumn{3}{|c|}{ Chemical Composition } \\
\hline Dry Matter & 871.2 & 870.6 \\
\hline Crude Protein & 150.0 & 136.7 \\
\hline Neutral Detergent Fiber & 382.6 & 380.1 \\
\hline Acid Detergent Fiber & 201.4 & 200.1 \\
\hline Ethereal Extract & 34.6 & 35.4 \\
\hline Total Digestible Nutrients & 666.7 & 670.9 \\
\hline Phosphorus & 7.2 & 3.3 \\
\hline
\end{tabular}

Vitamin E supplementation occurred once a week throughout the experimental period. A dose of $3 \mathrm{~mL}$ of vitamin $\mathrm{E}$ (acetate-alpha-tocopherol), equivalent to $300 \quad \mathrm{mg}$, was administered subcutaneously. The animals of the treatments without supplementation received placebo (saline solution) to be submitted to the same stress.

Next, $4 \mathrm{~mL}$ of blood were collected from each lamb in the morning (before feeding and water) under aseptic conditions by jugular vein puncture, in vacutainer-type flasks without anticoagulante on days 0 , $15,30,45,60$ and 75 . The vials were kept in an inclined position without disturbance immediately after blood collection. The samples were centrifuged at $3000 \mathrm{rpm}$ for 10 minutes to separate the clear serum, which was collected in 2 $\mathrm{mL}$ microtubes and stored at $-20{ }^{\circ} \mathrm{C}$ for further analysis.

Laboratory analyzes were performed at the CERNITAS Laboratory (a laboratory accredited by MAPA, belonging to the
National Network of Agricultural Laboratories, ordinance no. 60, of $22 / 04 / 2008$ ). Serum concentrations of total calcium (Labtest method), phosphorus (Basques-Lustosa method), magnesium (Labtest method), iron (Goodwil method), total protein (Biuret method), albumin (Bromocresol Blue method) urea (Urease method) and creatinine (Kinetic method) were evaluated, as well as the plasma glucose content (Orthotoluidine method) and the serum activities of the enzymes aspartate-amino-transferase - AST (Reitman-Frankel method), gammaglutamyl -transferase - GGT (modified Szasz method) and alkaline phosphatase - ALP (Labtest method). All samples were analyzed in a semiautomatic spectrophotometer at specific wavelengths for each constituent and in a selective ion doser.

Data were submitted to analysis of variance using the $F$ test and the comparison of means test using Tukey's 
test at the 5\% level by the SPSS version 22 statistical software program (IBM Corporation, New York, USA).

\section{RESULTS}

Mineral profile
There was no effect of the interaction between castration and vitamin $\mathrm{E}$ supplementation $(\mathrm{P}>0.05)$ in relation to blood calcium and magnesium concentrations (Table 2). An effect $(\mathrm{P}>0.05)$ was verified over time for all variables of the mineral profile in animals that received supplementation.

Table 2. Mean values for mineral profile of castrated and uncastrated goats, supplemented or not with vitamin $\mathrm{E}$

\begin{tabular}{|c|c|c|c|c|c|c|c|c|c|c|}
\hline \multirow{2}{*}{ Variable } & \multirow{2}{*}{ Treatment } & \multicolumn{6}{|c|}{ Days } & \multirow{2}{*}{ EPM } & \multicolumn{2}{|c|}{ P-value } \\
\hline & & 0 & 15 & 30 & 45 & 60 & 75 & & $\mathrm{~T}^{1}$ & $\mathrm{D}^{2}$ \\
\hline \multirow{4}{*}{$\begin{array}{l}\text { Calcium, } \\
\text { mg.dL }{ }^{-1}\end{array}$} & CYE & 10.47 & 11.30 & 10.42 & 10.13 & 10.90 & 10.88 & 0.20 & \multirow{2}{*}{0.242} & \multirow{2}{*}{0.127} \\
\hline & $\mathrm{CNE}$ & $10.55 \mathrm{ab}$ & $11.28 \mathrm{a}$ & $10.28 \mathrm{ab}$ & $10.10 \mathrm{~b}$ & $10.10 \mathrm{~b}$ & $10.23 \mathrm{ab}$ & 0.20 & & \\
\hline & UYE & 9.95 & 11.03 & 10.75 & 10.22 & 10.67 & 11.02 & 0.20 & \multirow{2}{*}{0.172} & \multirow{2}{*}{0.088} \\
\hline & UNE & $9.47 b$ & $10.78 \mathrm{a}$ & $10.15 \mathrm{ab}$ & $10.47 \mathrm{ab}$ & $10.70 \mathrm{a}$ & $10.55 \mathrm{ab}$ & 0.19 & & \\
\hline \multirow{4}{*}{$\begin{array}{c}\text { Phosphorus, } \\
\text { mg.dL }\end{array}$} & CYE & $6.10 \mathrm{a}$ & $6.13 a$ & $2.00 \mathrm{c}$ & $2.70 b c$ & $3.45 b$ & $3.28 b$ & 0.15 & \multirow{2}{*}{0.668} & \multirow{2}{*}{$<0.001$} \\
\hline & $\mathrm{CNE}$ & $6.78 b$ & $7.95 \mathrm{a}$ & $2.28 \mathrm{c}$ & $2.60 \mathrm{c}$ & $2.17 \mathrm{c}$ & $2.37 \mathrm{c}$ & 0.15 & & \\
\hline & UYE & $6.69 a$ & $6.03 a$ & $2.30 \mathrm{~b}$ & $2.58 b$ & $3.45 b$ & $3.45 b$ & 0.18 & \multirow{2}{*}{0.999} & \multirow{2}{*}{$<0.001$} \\
\hline & UNE & $6.17 \mathrm{a}$ & $6.55 \mathrm{a}$ & $2.37 \mathrm{c}$ & $2.40 \mathrm{bc}$ & $3.43 \mathrm{bc}$ & $3.60 \mathrm{~b}$ & 0.18 & & \\
\hline \multirow{4}{*}{$\begin{array}{l}\text { Magnesium, } \\
\text { mg.dL }\end{array}$} & CYE & 1.98 & 1.80 & 1.72 & 2.12 & 1.82 & 1.96 & 0.11 & \multirow{2}{*}{0.421} & \multirow{2}{*}{0.399} \\
\hline & $\mathrm{CNE}$ & $2.05 \mathrm{ab}$ & $1.70 \mathrm{~b}$ & $2.37 \mathrm{a}$ & $1.86 \mathrm{~b}$ & $2.08 \mathrm{ab}$ & $2.07 \mathrm{ab}$ & 0.11 & & \\
\hline & UYE & $1.98 \mathrm{ab}$ & $1.73 b$ & $1.90 \mathrm{ab}$ & $2.35 \mathrm{a}$ & $1.71 b$ & $1.98 \mathrm{ab}$ & 0.08 & & \\
\hline & UNE & 1.95 & 1.98 & 2.20 & 1.89 & 2.12 & 2.03 & 0.08 & 0.430 & 0.05 \\
\hline \multirow{4}{*}{ Iron, mg.dL ${ }^{-1}$} & CYE & $145.85 \mathrm{a}$ & $114.15 b$ & $33.71 d$ & $29.96 \mathrm{~d}$ & $80.50 \mathrm{c}$ & $80.33 c$ & 3.75 & \multirow{2}{*}{0.982} & \multirow{2}{*}{$<0.001$} \\
\hline & CNE & $151.60 \mathrm{a}$ & $116.11 b$ & $33.19 \mathrm{~d}$ & $31.83 \mathrm{~d}$ & $77.17 \mathrm{c}$ & $75.33 \mathrm{c}$ & 3.94 & & \\
\hline & UYE & $144.08 \mathrm{a}$ & $137.17 \mathrm{a}$ & $36.33 c$ & $29.75 c$ & $95.20 \mathrm{~b}$ & $83.33 b$ & 3.48 & \multirow{2}{*}{0.356} & \multirow{2}{*}{$<0.001$} \\
\hline & UNE & $159.65 \mathrm{a}$ & $145.50 \mathrm{a}$ & $35.50 \mathrm{c}$ & $33.56 \mathrm{c}$ & $56.90 \mathrm{bc}$ & $71.16 b$ & 3.48 & & \\
\hline
\end{tabular}

CYE: Castrated with vitamin E. CNE: Castrated without vitamin E. UYE: Uncastrated with vitamin E. UNE: Uncastrated without vitamin E. ${ }^{1}$ : Treatment. ${ }^{2}$ : Days.

Different lowercase letters indicate significant difference in serum analyte concentrations over time.

\section{Protein and energy profile}

There was an effect of time on serum protein concentrations for the treatment without castration $(\mathrm{P}<0.05)$ (Table 3). There was an effect of time between treatments for albumin, urea and creatinine concentrations $(\mathrm{P}<0.05)$, with the last two showing peaks at 45 days. There was an effect of time and vitamin supplementation $(\mathrm{P}<0.05)$ for glucose, with a peak at 45 and 60 days.

Table 3. Mean values for protein and energy profile of castrated and uncastrated goats, supplemented with vitamin $\mathrm{E}$ or not

\begin{tabular}{|c|c|c|c|c|c|c|c|c|c|c|}
\hline \multirow{2}{*}{ Variable } & \multirow{2}{*}{ Treatment } & \multicolumn{6}{|c|}{ Days } & \multirow{2}{*}{ EPM } & \multicolumn{2}{|c|}{ P-value } \\
\hline & & 0 & 15 & 30 & 45 & 60 & 75 & & $\mathrm{~T}^{1}$ & $\overline{\mathrm{D}^{2}}$ \\
\hline $\begin{array}{l}\text { Protein, } \\
\text { mg.dL }\end{array}$ & $\begin{array}{l}\text { CYE } \\
\text { CNE }\end{array}$ & $\begin{array}{c}6.57 \mathrm{a} \\
5.82\end{array}$ & $\begin{array}{c}5.96 \mathrm{ab} \\
6.43\end{array}$ & $\begin{array}{c}5.68 \mathrm{ab} \\
5.92\end{array}$ & $\begin{array}{c}5.16 b \\
5.36\end{array}$ & $\begin{array}{c}5.60 \mathrm{ab} \\
5.32\end{array}$ & $\begin{array}{c}5.83 \mathrm{ab} \\
5.40\end{array}$ & $\begin{array}{l}0.24 \\
0.25\end{array}$ & 0.839 & 0.313 \\
\hline
\end{tabular}




\begin{tabular}{|c|c|c|c|c|c|c|c|c|c|c|}
\hline & $\begin{array}{l}\text { UYE } \\
\text { UNE }\end{array}$ & $\begin{array}{l}6.58 \mathrm{a} \\
5.17 \mathrm{~b}\end{array}$ & $\begin{array}{l}5.72 \mathrm{ab} \\
5.62 \mathrm{ab}\end{array}$ & $\begin{array}{c}5.12 \mathrm{~b} \\
5.49 \mathrm{ab}\end{array}$ & $\begin{array}{l}4.50 \mathrm{~b} \\
6.68 \mathrm{ab}\end{array}$ & $\begin{array}{c}6.68 \mathrm{a} \\
6.80 \mathrm{ab}\end{array}$ & $\begin{array}{l}6.23 \mathrm{a} \\
6.82 \mathrm{a} \\
\end{array}$ & $\begin{array}{l}0.11 \\
0.12 \\
\end{array}$ & 0.064 & 0.028 \\
\hline \multirow{3}{*}{$\begin{array}{l}\text { Albumin, } \\
\text { g.dL }\end{array}$} & CYE & $1.88 \mathrm{~b}$ & $2.48 \mathrm{a}$ & $0.93 b$ & $1.33 \mathrm{~b}$ & $2.17 \mathrm{a}$ & $2.15 a$ & 0.09 & \multirow[t]{2}{*}{0.370} & \multirow[t]{2}{*}{$<0.001$} \\
\hline & $\mathrm{CNE}$ & $1.84 \mathrm{a}$ & $2.10 \mathrm{a}$ & $1.02 \mathrm{~b}$ & $1.55 \mathrm{~b}$ & $1.95 \mathrm{a}$ & $2.12 \mathrm{a}$ & 0.09 & & \\
\hline & $\begin{array}{l}\text { UYE } \\
\text { UNE }\end{array}$ & $\begin{array}{c}1.95 \mathrm{~b} \\
1.75 \mathrm{ab}\end{array}$ & $\begin{array}{l}2.48 \mathrm{a} \\
2.22 \mathrm{a}\end{array}$ & $\begin{array}{l}1.11 \mathrm{c} \\
1.15 \mathrm{~b}\end{array}$ & $\begin{array}{l}1.30 \mathrm{c} \\
1.32 \mathrm{~b}\end{array}$ & $\begin{array}{l}1.75 b c \\
2.02 \mathrm{a}\end{array}$ & $\begin{array}{c}1.71 b c \\
2.20 \mathrm{a}\end{array}$ & $\begin{array}{l}0.06 \\
0.06\end{array}$ & 0.503 & $<0.001$ \\
\hline \multirow{2}{*}{$\begin{array}{l}\text { Urea, } \\
\text { g.dL }\end{array}$} & $\begin{array}{l}\text { CYE } \\
\text { CNE }\end{array}$ & $\begin{array}{c}42.83 \\
39.83 b\end{array}$ & $\begin{array}{c}37.33 \\
36.67 \mathrm{c}\end{array}$ & $\begin{array}{c}37.67 \\
41.17 \mathrm{abc}\end{array}$ & $\begin{array}{c}45.81 \\
53.80 \mathrm{a}\end{array}$ & $\begin{array}{c}46.17 \\
51.70 \mathrm{ab}\end{array}$ & $\begin{array}{c}46.20 \\
51.67 \mathrm{ab}\end{array}$ & $\begin{array}{l}1.98 \\
2.01\end{array}$ & 0.269 & 0.025 \\
\hline & $\begin{array}{l}\text { UYE } \\
\text { UNE }\end{array}$ & $\begin{array}{c}43.50 \\
41.67 \mathrm{ab}\end{array}$ & $\begin{array}{c}31.33 \\
33.67 \mathrm{~b}\end{array}$ & $\begin{array}{c}43.67 \\
44.50 \mathrm{ab}\end{array}$ & $\begin{array}{c}42.40 \\
52.00 \mathrm{a}\end{array}$ & $\begin{array}{c}42.67 \\
49.55 \mathrm{a}\end{array}$ & $\begin{array}{c}42.72 \\
49.50 \mathrm{a}\end{array}$ & $\begin{array}{l}2.70 \\
2.75\end{array}$ & 0.291 & 0.016 \\
\hline \multirow{2}{*}{$\begin{array}{l}\text { Creatinine, } \\
\text { g.dL } \mathrm{dL}^{-1}\end{array}$} & $\begin{array}{l}\text { CYE } \\
\text { CNE }\end{array}$ & $\begin{array}{c}0.72 \mathrm{ab} \\
0.63\end{array}$ & $\begin{array}{c}0.67 b \\
0.65\end{array}$ & $\begin{array}{c}0.83 \mathrm{ab} \\
0.99\end{array}$ & $\begin{array}{c}0.92 \mathrm{ab} \\
1.00\end{array}$ & $\begin{array}{c}0.93 \mathrm{a} \\
0.68\end{array}$ & $\begin{array}{c}0.93 \mathrm{a} \\
0.69\end{array}$ & $\begin{array}{l}0.04 \\
0.04\end{array}$ & 52 & 0.010 \\
\hline & $\begin{array}{l}\text { UYE } \\
\text { UNE }\end{array}$ & $\begin{array}{l}0.62 \mathrm{~b} \\
0.70 \mathrm{~b}\end{array}$ & $\begin{array}{c}0.68 \mathrm{~b} \\
0.73 \mathrm{ab}\end{array}$ & $\begin{array}{c}0.82 \mathrm{ab} \\
0.97 \mathrm{a}\end{array}$ & $\begin{array}{l}0.99 \mathrm{a} \\
0.97 \mathrm{a}\end{array}$ & $\begin{array}{c}0.98 \mathrm{a} \\
0.88 \mathrm{ab}\end{array}$ & $\begin{array}{c}0.97 \mathrm{a} \\
0.89 \mathrm{ab}\end{array}$ & $\begin{array}{l}0.04 \\
0.04\end{array}$ & 0.811 & $<0.001$ \\
\hline \multirow{2}{*}{$\begin{array}{l}\text { Glucose } \\
\text { g.dL }\end{array}$} & $\begin{array}{l}\text { CYE } \\
\text { CNE }\end{array}$ & $\begin{array}{c}41.67 \mathrm{c} \\
63.23 \mathrm{bc}\end{array}$ & $\begin{array}{c}50.96 \mathrm{bc} \\
54.38 \mathrm{c}\end{array}$ & $\begin{array}{l}76.17 b \\
81.93 b\end{array}$ & $\begin{array}{l}148.72 \mathrm{a} \\
118.62 \mathrm{a}\end{array}$ & $\begin{array}{l}168.13 a \\
139.41 a\end{array}$ & $\begin{array}{l}60.00 \mathrm{bc} \\
73.67 \mathrm{bc}\end{array}$ & $\begin{array}{l}3.70 \\
3.70\end{array}$ & 0.648 & $<0.001$ \\
\hline & $\begin{array}{l}\text { UYE } \\
\text { UNE }\end{array}$ & $\begin{array}{c}65.41 b c \\
70.10 \mathrm{c}\end{array}$ & $\begin{array}{c}67.41 b c \\
42.15 c\end{array}$ & $\begin{array}{l}90.11 \mathrm{~b} \\
56.73 \mathrm{c}\end{array}$ & $\begin{array}{l}125.44 a \\
122.64 b\end{array}$ & $\begin{array}{l}137.74 a \\
150.49 a \\
\end{array}$ & $\begin{array}{l}63.00 \mathrm{c} \\
59.17 \mathrm{c}\end{array}$ & $\begin{array}{l}3.84 \\
3.84\end{array}$ & 0.049 & $<0.001$ \\
\hline
\end{tabular}

CYE: Castrated with vitamin E. CNE: Castrated without vitamin E. UYE: Uncastrated with vitamin E. UNE: Uncastrated without vitamin E. ${ }^{1}$ : Treatment. ${ }^{2}$ : Days.

Different lowercase letters indicate significant difference in serum analyte concentrations over time.

Enzyme profile

There was an effect of vitamin supplementation $(\mathrm{P}<0.05)$ for aspartate aminotransferase (AST) and alanine aminotransferase (ALP), peaking at 75 days and 45 and 60 days, respectively
(Table 4). For the gammaglutamyltransferase (GGT) variable, there was an effect $(\mathrm{P}<0.05)$ of the animal condition at 45 days (fourth collection).

Table 4. Mean values for enzymatic profile of castrated and uncastrated goats, supplemented with vitamin $\mathrm{E}$ or not

\begin{tabular}{|c|c|c|c|c|c|c|c|c|c|c|}
\hline \multirow{2}{*}{ Variable } & \multirow{2}{*}{ Treatment } & \multicolumn{6}{|c|}{ Days } & \multirow{2}{*}{ EPM } & \multicolumn{2}{|c|}{$\mathrm{P}$-value } \\
\hline & & 0 & 15 & 30 & 45 & 60 & 75 & & $\mathrm{~T}^{1}$ & $\mathrm{D}^{2}$ \\
\hline \multirow{4}{*}{$\begin{array}{l}\text { AST, } \\
\text { UI.L }^{-1}\end{array}$} & CYE & $70.33 b$ & $72.33 b$ & $49.41 c$ & $39.91 \mathrm{c}$ & $68.83 b$ & $159.86 a$ & 2.44 & \multirow{2}{*}{0.001} & \multirow{2}{*}{$<0.001$} \\
\hline & CNE & $81.17 \mathrm{~b}$ & $82.00 \mathrm{~b}$ & $65.00 \mathrm{bc}$ & $58.80 \mathrm{c}$ & $73.83 b$ & $139.41 \mathrm{a}$ & 2.28 & & \\
\hline & UYE & $72.00 \mathrm{~b}$ & $70.66 b$ & $50.16 c$ & $46.00 \mathrm{c}$ & $67.16 b c$ & $132.97 \mathrm{a}$ & 2.35 & \multirow{2}{*}{0.022} & \multirow{2}{*}{$<0.001$} \\
\hline & UNE & $80.16 b$ & $77.80 \mathrm{~b}$ & $68.66 \mathrm{bc}$ & $56.00 \mathrm{c}$ & $64.83 b c$ & $139.22 \mathrm{a}$ & 2.41 & & \\
\hline \multirow{4}{*}{$\begin{array}{l}\text { ALP, } \\
\text { UI.L }\end{array}$} & CYE & $48.44 \mathrm{a}$ & $55.32 \mathrm{a}$ & $25.20 \mathrm{~b}$ & $54.51 \mathrm{a}$ & $59.22 \mathrm{a}$ & $41.01 b$ & 1.88 & \multirow{2}{*}{0.002} & \multirow{2}{*}{$<0.001$} \\
\hline & $\mathrm{CNE}$ & $63.31 \mathrm{~b}$ & $72.04 \mathrm{ab}$ & $26.81 \mathrm{c}$ & $64.23 \mathrm{ab}$ & $75.07 \mathrm{a}$ & $35.81 \mathrm{c}$ & 1.88 & & \\
\hline & UYE & $43.20 \mathrm{~b}$ & $49.50 \mathrm{~b}$ & $29.80 \mathrm{c}$ & $69.83 a$ & $62.50 \mathrm{a}$ & $37.16 b c$ & 2.77 & \multirow{2}{*}{0.362} & \multirow{2}{*}{$<0.001$} \\
\hline & UNE & $59.80 \mathrm{a}$ & $61.00 \mathrm{a}$ & $30.20 \mathrm{c}$ & $59.84 \mathrm{a}$ & $57.50 \mathrm{ab}$ & $41.66 b c$ & 2.77 & & \\
\hline \multirow{4}{*}{$\begin{array}{l}\text { GGT, } \\
\text { UI.L }^{-1}\end{array}$} & CYE & $37.33 b$ & $37.67 b$ & $60.50 \mathrm{a}$ & $39.33 b$ & $41.00 \mathrm{~b}$ & $61.19 \mathrm{a}$ & 1.90 & \multirow{2}{*}{0.927} & \multirow{2}{*}{$<0.001$} \\
\hline & CNE & $41.17 \mathrm{~b}$ & $41.00 \mathrm{~b}$ & $54.83 \mathrm{a}$ & $36.50 \mathrm{~b}$ & $35.83 \mathrm{~b}$ & $66.22 \mathrm{a}$ & 1.90 & & \\
\hline & UYE & $40.50 \mathrm{~b}$ & $40.50 \mathrm{~b}$ & $52.17 \mathrm{~b}$ & $32.17 \mathrm{c}$ & $37.17 \mathrm{c}$ & $67.17 \mathrm{a}$ & 1.90 & \multirow{2}{*}{0.652} & \multirow{2}{*}{$<0.001$} \\
\hline & UNE & $38.16 \mathrm{~b}$ & $40.50 \mathrm{~b}$ & $50.50 \mathrm{ab}$ & $45.66 \mathrm{~b}$ & $41.66 \mathrm{~b}$ & $60.53 \mathrm{a}$ & 1.93 & & \\
\hline
\end{tabular}


AST: aspartate aminotransferase. ALP: alanine aminotransferase. GGT: gama-glutamyltransferase. CYE: Castrated with vitamin E. CNE: Castrated without vitamin E. UYE: Uncastrated with vitamin E. UNE: Uncastrated without vitamin E. ${ }^{1}$ : Treatment. ${ }^{2}$ : Days.

Different lowercase letters indicate significant difference in serum analyte concentrations over time.

\section{DISCUSSION}

Minerals are of fundamental importance for ruminants, being present in fluids and tissues, and having basic functions such as tissue structure, assisting in acid-base balance, osmotic pressure and cell membrane permeability (Soetan et al., 2010). Calcium (CA) levels (Table 2) were within the normal range for goats, ranging from 9.5 to $11.4{\mathrm{mg} . \mathrm{dL}^{-1}}^{-1}$ throughout the entire experimental period, which is consistent with findings in other studies ( Duarte et al., 2011; Kaneko et al., 2008; Lima et al., 2021). Castrated animals showed differences $(\mathrm{P}<0.05)$ over time for CA levels, but no information was found in the consulted literature to justify the observed fact, since castration alters hormonal metabolism and animal development.

The main functions of calcium are to form and maintain teeth and bones, muscle contraction, regulate hear rate, transmit nerve impulses and secrete hormones, and it has a direct interaction with phosphorus $(\mathrm{P})$, in which the excess of both minerals can lead to a decrease in their absorption (Fayer \& Bengoumi, 2018).

Serum phosphorus $(\mathrm{P})$ concentrations for all treatments (Table 2) until the second collection remained within the reference values (4.2 to $9.1 \mathrm{mg} . \mathrm{dL}^{-1}$ ) (Kaneko et al., 2008), however, there was a decrease in the concentration from the third collection onwards, which ranged from 2 to $3.6 \mathrm{mg} . \mathrm{dL}^{-1}$ between the treatments studied, and this fact may have occurred due to the physiological variation of the animal due to its advancing age (Lima et al., 2021).
Magnesium (Mg) values were within the range reported for small ruminants by Chester-Jones et al. (1990) and Boyd (1984) $\left(1.92 \mathrm{mg} / \mathrm{dL}^{-1}\right.$ and 2.19 to 2.92 $\mathrm{mg} / \mathrm{dL}^{-1}$, respectively). Soetan et al. (2010) reports that this mineral is absorbed in the intestine and subsequently transported to the blood, cells and tissues, where problems in the digestive tract and kidneys can influence absorption, and consequently, changes in serum magnesium levels. Weakening of the hair and roughness is observed when $\mathrm{Mg}$ is deficient in the diet in young animals, leading to the animals having a stunted appearance, and in extreme cases convulsions leading to death (Merck, 1986).

The serum iron $(\mathrm{Fe})$ concentration in this study ranged from 29.8 to $159.7{\mathrm{mg} . \mathrm{dL}^{-1}}^{-1}$ (Table 2), being close to the reference values ranging from 39 to $207 \mathrm{mg} . \mathrm{dL}^{-1}$ (Kaneko et al., 2008; Smith, 1997). Concentrations above $218 \mathrm{mg} \cdot \mathrm{dL}^{-1}$ can be considered an overload, which can cause liver damage, with advancing age of the animal being a greater susceptibility to this overload (Kaneko et al., 2008).

Vitamin E supplementation can reduce iron toxicity (Kaneko et al., 2008) in addition, reduced testosterone levels can decrease iron absorption, and its incorporation mainly occurs in red blood cells and hemoglobin synthesis (Olaifa, 2018).

In a study carried out by Lima et al. (2021) with goats fed on native pasture with or without mineral supplementation, the authors found higher values than those found in this study for iron, which ranged from 189.3 
to $293.7 \mathrm{mg} . \mathrm{dL}^{-1}$, and from 167.5 to $245.7 \mathrm{mg} . \mathrm{dL}^{-1}$, respectively. The authors reported that the highest concentrations for non-supplemented animals came from involuntary soil ingestion, since there is a shortage of forage at some time of the year.

All groups showed a decrease in total protein concentration on some of the days studied (Table 3), differing from the reference value range, which is 6.4 to 7.0 mg.dL ${ }^{-1}$ for goat species (Kaneko et al. al., 2008). The concentration of total proteins is reduced in liver failure, intestinal and kidney disorders, hemorrhage or dietary deficiency (Gonzalez \& Silva, 2008). It was observed that the total protein content increased throughout the experiment, remaining within the reference values in the last two collections, mainly for noncastrated animals. In evaluating the biochemical profile of lactating goats fed diets containing $0,7,14$ and $21 \%$ of crude glycerin from the production of biodiesel from frying oil, Santos et al. (2018) found that the different crude glycerin percentages vin the diet did not affect the concentrations of total proteins.

Serum albumin concentration was below the acceptable range for all treatments according to Raju et al. (2015) (14.74 $\mathrm{gL}^{-}$ ${ }^{1}$ ), and this can predict an indication of liver dysfunction, although there are other parameters such as aspartate aminotransferase (AST), alanine aminotransferase (ALP), alkaline and acid phosphatase that assertively investigate this dysfunction (Tripathi et al., 2008).

The increase in urea levels (Table 3) throughout the collections, especially for castrated animals, corroborates AlZghoul et al. (2008) and Olaifa \& Opara (2011), since urea acts as a source of nitrogen for protein biosynthesis, where the intense breakdown of protein leads to ammonia formation, which can cause intoxication in the animal (Harmeyer \& Martens, 1980; Olaifa \& Opara, 2011). Castration causes inflammatory trauma in the animal, leading to changes in protein absorption, and consequently, an increase in urea production.

When studying different times after castration, Kayode \& Obot (2017) observed that the urea concentration in the blood of goats increased due to the increase in cortisol levels, as this stress caused by castration increases the breakdown of proteins and nucleic acids in the muscles due to the increase in this hormone.

Soul et al. (2019) state that creatinine is formed in skeletal muscle through the degradation of serum phosphocretin for energy production, in which creatinine levels are directly proportional to the amount of muscle mass (Carlos et al., 2015). Therefore, an increase in creatinine levels was observed over time, which may be related to a reduction in thyroxine activity (Soul et al., 2019) in turn, castrated animals without supplementation had a drop in creatinine levels from 60 days of collection (Table 3 ), leading to the belief that they had maximized efficiency energy use.

The results found herein were superior to those found by Olaifa (2018) for creatinine levels (Table 3). This same author reports that creatinine is removed from the blood through glomerular filtration and by proximal tubular secretion through the kidneys, and is commonly used as an indicator to presuppose renal function.

It is observed that vitamin $\mathrm{E}$ supplementation tended to increase glucose levels in goats (Table 3), corroborating Ziaei (2014) that when 
supplementing goats up to the level of $50 \mathrm{mg} \cdot \mathrm{kg}^{-1}$ of vitamin E, glucose considerably increased. Some studies indicate that weaning, rumen development, dietary and physiological changes cause changes in ruminant blood glucose (Baldwin et al., 2004; Mccarthy \& Kesler, 1956; Redlberger et al., 2017). The literature reports that the blood glucose of adult goats ranges from 60 to $190 \mathrm{mg}$.dL ${ }^{-1}$ (Kaneko, 1989; Pérez et al., 2003; Yanaka et al., 2012).

The aspartate aminotransferase (AST) concentrations found ranged from 39.9 to 159.9 IU.L ${ }^{-1}$ (Table 4), differing from the values adopted as reference for goats, which is from 167 to 513 IU.L $^{-1}$ (Kaneko, 1989). However, there is still a lot of divergence in the literature regarding AST variations as a function of the age of the animal (Yanaka et al., 2012). Gwaze et al. (2012) report that food availability can affect AST levels, because it is correlated with muscle growth, and with correct liver functioning.

The concentration of alanine aminotransferase (ALP) levels when the animals received the supplementation ranged from 25.2 to 75.0 IU.L ${ }^{-1}$ (Table 4), being below the reference range for the goat species, which is 93 at 387 IU.L $^{-}$ ${ }^{1}$ (Kaneko, 1989). However, serum ALP values in goats can increase up to temfold without liver damage (Yanaka et al., 2012), and the elevation can occur during periods that involve increased bone activity, such as the growth phase (Gwaze et al., 2012).

Gwaze et al. (2012) reported negative interaction of ALP with increased age of the animals, since this enzyme is highly related to the calcification process, so bone development is accelerated when the animals are young, and Kaneko et al. (2008) claim that this enzyme also helps in the development of the gastrointestinal tract.

The gamma glutamyltransferase (GGT) concentrations found ranged from 32.2 to 67.2 IU.L $^{-1}$ (Table 4) throughout the experimental period, in agreement with the reference values of Pérez et al. (2003) from 26 to 77 IU.L ${ }^{-1}$.

\section{CONCLUSIONS}

Castration did not influence the biochemical profile of goats, regardless of whether they were supplemented with vitamin $\mathrm{E}$ or not. Vitamin supplementation increased glucose, creatinine and gammaglutamyltransferase (GTT) levels over time, and reduced the amount of phosphorus, iron, protein, albumin, aspartate aminotransferase (AST) and alanine aminotransferase (ALP).

\section{ACKNOWLEDGEMENT}

The authors thank the Instituto Federal do Maranhão - Campus Maracanã, the Fundação de Amparo à Pesquisa e ao Desenvolvimento Científico $e$ Tecnológico do Maranhão - FAPEMA and the Coordination for the Improvement of Higher Education Personnel - CAPES, for their financial and logistical support.

\section{REFERENCES}

AL-ZGHOUL, M.; AL-RUKIBAT, R.; TALAFHA, A.; ABABNEH, O.; ISMAIL, Z. Cellular and some biochemical changes in blood and peritoneal fluid constituents in Awassi lambs following elective castration. American Journal of Animal and Veterinary Sciences, v.3, n.1, p.23-27, 2008. 
https://doi.org/10.3844/ajavsp.2008.23. 27.

BALDWIN, R.L.; MCLEOD, K.R.; KLOTZ, J.L.; HEITMANN, R.N. Rumen development, intestinal growth and hepatic metabolism in the pre-and postweaning ruminant. Journal of Dairy Science, v.87, p.E55-E65, 2004. https://doi.org/10.3168/jds.S00220302(04)70061-2.

BOYD, J.W. The interpretation of serum biochemistry test results in domestic animals. Veterinary

Clinical

Pathology, v. 13, n. 2, p. 7 - 14, 1984.

CAMARGO, E.V.; LOPES, S.T.A.; COSTA, M.M.; PAIM, F.; BARBOSA, C.S.; LEAL, M.L.R. Neutrophil oxidative metabolism and haemogram of sheep experimentally infected with Haemonchus contortus and supplemented with selenium and vitamin E. Journal of Animal Physiology and Animal Nutrition, v.94, n.5, p.e1-e6, 2010. https://doi.org/10.1111/j.14390396.2010.00986.x.

CARLOS, M.M.L.; LEITE, J.H.G.M.; CHAVES, D.F.; VALE, A.M.; FAÇANHA, D.A.E.; MELO, M.M.; SOTO-BLANCO, B. Blood parameters in the Morada Nova sheep: influence of age, sex and body condition score. The Journal of Animal \& Plant Sciences, v.25, n.4, p.950-955, 2015.

CHESTER-JONES, H.; FONTENOT, J.P.; VEIT, H.P. Physiological and pathological effects of feeding high levels of magnesium to steers. Journal of Animal Science, v. 68, n. 12, p. 4400 $-4413,1990$.
DUARTE， A.L.L.; PIRES， M.D.S.; BARBOSA, R.R.; DIAS, R.D.C.; SOTO-BLANCO, B. Evaluation of phosphorus deficiency in ruminants by serum biochemistry. Acta Veterinaria Brasilica, v.5, n.4, p.380-384, 2011.

FAYE, B.; BENGOUMI, M. Macrominerals and Electrolytes. In: Camel Clinical Biochemistry and Hematology. Springer, Cham, p.173216, 2018.

GONZALEZ, F.H.D.; SILVA, S.C. Patologia Clínica Veterinária: Texto Introdutório. Porto Alegre, Universidade Federal do Rio Grande do Sul, 2008.

GUPTA, V.; BHASIN, S.; GUO, W.; SINGH, R.; MIKIC, R.; CHAUHAN, P.; CHOONG, K.; TCHKONIA, T.; LEBRASSEUR, N.K.; FLANAGAN, J.N.; HAMILTON, J.A.; VIERECK, J.C.; NARULA, N.S.; KIRKLAND, J.L.; JASUJA, R. Effects of dihydrotestosterone on differentiation and proliferation of human mesenchymal stem cells and preadipocytes. Molecular and Cellular Endocrinology, v.296, n.1-2, p.32-40, 2008.

https://doi.org/10.1016/j.mce.2008.08.0 19.

GWAZE， F.R.; CHIMONYO, M.; DZAMA, K. Effect of season and age on blood minerals, liver enzyme levels, and faecal egg counts in Nguni goats of South Africa. Czech Journal Animal Science, v. 57, n. 10, p. 443 - 453, 2012.

HARMEYER, J.; MARTENS, H. Aspects of urea metabolism in ruminants with reference to the goat. Journal of Dairy Science, v.63, n.10, p.1707-1728, 
1980. https://doi.org/10.3168/jds.S00220302(80)83132-8.

KAYODE, O.A.; OBOT, A.M. Acute biochemical and Hematological responses to Bur dizzo castration in West African Dwarf bucks. E3 Journal of Medical Research, v.6, n.1, p.6-11, 2017.

http://dx.doi.org/10.18685/EJMR(6)1_E JMR-16-014.

KANEKO, J.J. (Ed.). Clinical Biochemistry of Domestic Animals. 4. ed. San Diego: Academic Press, 1989. $932 \mathrm{p}$.

KANEKO, J.J.; HARVEY, J.W.; BRUSS, M.L. (Ed.). Clinical Biochemistry of Domestic Animals. Academic press, 2008.

LIMA，J.M.; VALE， R.G.; SOUSA, R.D.S.; NUNES, T.L.; GAMELEIRA, J.D.S.; CAVALCANTE, J.M.; MINERVINO, A.H.H.; ORTOLANI, E.L.; BARRÊTO JÚNIOR, R.A. Seasonality Effects on the Mineral Profile of Goats Farmed in the Semiarid Region of Brazil. Veterinary Sciences, v. $8, \quad$ n. $1, \quad$ p. $8,2021$. https://doi.org/10.3390/vetsci8010008.

MCCARTHY, R.D.; KESLER, E.M. Relation between age of calf, blood glucose, blood and rumen levels of volatile fatty acids, and in vitro cellulose digestion. Journal of Dairy Science, v.39, n.9, p.1280-1287, 1956. https://doi.org/10.3168/jds.S00220302(56)94846-9.

MENDONÇA JÚNIOR, A.F.; BRAGA, A.P.; RODRIGUES, A.P.M.S.; SALES, L.E.M. Vitaminas: uma abordagem prática de uso na alimentação de ruminantes. Agropecuária Científica no Semiárido, v.6, n.4, 2011. http://dx.doi.org/10.30969/acsa.v6i4.94.

MERCK, V. M. The Merck Veterinary Manual. A handbook of diagnosis, therapy and disease prevention and control for the veterinarian. Published by Merck and Co. Inc., Rahway, New Jersey, USA, v. 1677, 1986.

MOHAMMED, A.; JAMES, F.O. Chemical castration by a single bilateral intra-testicular injection of chlorhexidine gluconate and cetrimide in bucks. Sokoto Journal of Veterinary Sciences, v.11, n.1, p.62-65, 2013. http://dx.doi.org/10.4314 sokjvs.v11i1.10.

NRC - National Research Council. Nutrient requirements of dairy cattle. $1^{\circ}$.ed. Washington: D.C., 2007.

OLAIFA, A.K. Comparison in haematological and biochemical changes in normal, acute and chronically castrated West African Dwarf goats. International Journal of Research in Medical Sciences, v.6, n.5, p.1623-1627, 2018. http://dx.doi.org/10.18203/23206012.ijrms20181748.

OLAIFA, A.K.; OPARA, M.N. Haematological and biochemical parameters of West African Dwarf (WAD) bucks castrated by the Burdizzo method. Veterinarski arhiv, v.81, n.6, p.743-750, 2011.

PÉREZ， J.M.; GONZÁLEZ， F.J.; GRANADOS, J.E.; PÉREZ, M.C.; FANDOS, P.; SORIGUER, R.C.; SERRANO, E. Hematologic and biochemical reference intervals for 
spanish Ibex. Journal of Wildlife Diseases, v.39, n.1, p.209-215, 2003. https://doi.org/10.7589/0090-355839.1.209.

RAJU, J.; $\quad$ SAHOO, B.; CHANDRAKAR, A.; SANKAR, M.; GARG, A.K.; SHARMA, A.K.; PANDEY, A.B. Effect of feeding oak leaves (Quercus semecarpifolia vs Quercus leucotricophora) on nutrient utilization, growth performance and gastrointestinal nematodes of goats in temperate sub Himalayas. Small Ruminant Research, v.125, p.1-9, 2015.

https://doi.org/10.1016/j.smallrumres.20 14.12.013.

REDLBERGER, S.; FISCHER, S.; KÖHLER, H.; DILLER, R.; REINHOLD, P. Age-dependent physiological dynamics in acid-base balance, electrolytes, and blood metabolites in growing goats. The Veterinary Journal, v.229, p.45-52, 2017.

https://doi.org/10.1016/j.tvj1.2017.10.01 7.

SAMIMI, A.S.; AGHAMIRI, S.M.; NAZIFI, S.; ASADI, Z. Changes in ghrelin, microminerals, antioxidants and vitamins $\mathrm{A}, \mathrm{E}$ and $\mathrm{C}$ levels during different physiological status in high yielding Saanen goats subjected to heat stress. Journal of Thermal Biology, v.100, p.103014, 2021. https://doi.org/10.1016/j.jtherbio.2021.1 03014.

SANTOS, C.B.; ARAÚJO, M.J.; BEZERRA, L.R.; MARQUES, C.A.T.; TORREÃO, J.N.C.; FREITAS, N.E.; OLIVEIRA NETO, C.B.; MORAIS, J.S. Parâmetros hematológicos e bioquímicos de cabras lactantes alimentadas com dietas contendo glicerina bruta oriunda da produção de biodiesel proveniente de óleo de fritura. Arquivo Brasileiro de Medicina Veterinária e Zootecnia, v.70, n.6, p.1867-1876, 2018. https://doi.org/10.1590/1678-416210022.

SMITH, J.E. Iron metabolism and its disorders. In: Clinical Biochemistry of Domestic Animals. Academic press, 1997. p. 223-239. https://doi.org/10.1016/B978012396305-5/50010-5.

SOETAN, K.O.; OLAIYA, C.O.; OYEWOLE, O.E. The importance of mineral elements for humans, domestic animals and plants-A review. African Journal of Food Science, v.4, n.5, p.200-222, 2010. https://doi.org/10.5897/AJFS.9000287.

SOUL, W.; MUPANGWA, J.; MUCHENJE, V.; MPENDULO, T.C. Biochemical indices and heamtological parameters of goats fed lablab purpureus and vigna unguiculata as supplements to a chloris gayana basal diet. Veterinary and Animal Science, v.8, p.100073, 2019.

https://doi.org/10.1016/j.vas.2019.1000 73.

TEIXEIRA, W.C.; SANTOS, H.P.; VESCHI, J.L.A.; NASCIMENTO, S.A.; SILVA, J.C.R.; MARVULO, M.F.V.; RIZZO, H.; CASTRO, R.S. Prevalência da infecção pelo Vírus da Artrite Encefalite Caprina em rebanhos caprinos do estado do Maranhão, Brasil. Brazilian Journal of Veterinary Medicine, v.38, n.1, p.1-6, 2016. 
https://doi.org/10.2430/0000000000000 0 .

TRIPATHI, M. K.; MONDAL, D.; KARIM, S. A. Growth, haematology, blood constituents and immunological status of lambs fed graded levels of animal feed grade damaged wheat as substitute of maize. Journal of animal physiology and animal nutrition, v. 92, n. $1, \quad$ p. $75-85,2008$. https://doi.org/10.1111/j.1439-

0396.2007.00712.x.

YANAKA， R.; CAMARGO， D.G.; SANTOS, W.A.; SILVA, B.C.; BOVINO, F.; MENDES, L.C.N.; PEIRÓ, J.R.; FEITOSA, F.L.F. Glicemia, proteinograma e perfil de alguns componentes bioquímicos séricos de cabritos da raça Bôer. Brazilian Journal of Veterinary Research and Animal Science, v.49, n.1, p.30-38, 2012.

https://doi.org/10.11606/issn.23183659.v49i1p30-38.

ZIAEI, N. Effect of selenium and vitamin $\mathrm{E}$ supplementation on reproductive indices and biochemical metabolites in Raieni goats. Journal of Applied Animal Research, v.43, n.4, p.426-430,

2015. https://doi.org/10.1080/09712119.2014. 980415. 